\title{
EFFECT OF HEAT TREATMENT AND BATH COMPOSITION OF ELECTROLESS NICKEL-PLATING ON CAVITATION EROSION RESISTANCE
}

\author{
S. A. Karrab ${ }^{1, *}$, M. A. Doheim ${ }^{2}$, Mohammed S. Aboraia ${ }^{3}$, S.M. Ahmed ${ }^{4}$ \\ 1,2, 3 Mining and Metallurgical Engineering Department, Assiut University, Assiut 71516, Egypt \\ ${ }^{4}$ Mechanical Engineering Department, Majmaah University, SA
}

Received 27 July 2013; accepted 22 August 2013

\begin{abstract}
Electroless Nickel-Phosphorus coatings have had a lot of interest in various industries due to outstanding characteristics. Some of the highlighted characteristics of electroless Ni-P coatings are superior corrosion and wear resistance. But the effectiveness of electroless Ni-P coating in resisting cavitation damage is not studied so well and is not so clear. In the present investigation, electroless $\mathrm{Ni}-\mathrm{P}$ coatings were prepared at various conditions including the type of bath, heat treatment temperature and plating solutions composition. The properties of electroless Ni-P coatings were characterized using X-ray diffraction technique (XRD), energy dispersive X- ray (EDX) optical microscope, and microhardness tester. The cavitation erosion tests were carried out to study the effect bath type, heat treatment temperature and plating solutions composition on the deposit coatings.

The XRD results indicate that the as-deposit had crystalline structure for alkaline bath and amorphous structure for acid bath. Heat treatment of the coatings produced mixture of polycrystalline phases. The thickness of deposit films depend on the bath type and concentration and were the least for alkaline baths. Maximum hardness of heat treated samples was found to depend on the solution composition and occurs at temperature $300{ }^{\circ} \mathrm{C}$ and $400^{\circ} \mathrm{C}$.

The highest erosion resistance of the coatings was observed for the heat treated deposits at temperature of $650{ }^{\circ} \mathrm{C}$, and comes to the fore the coatings formed in alkaline baths followed by that formed in acid baths. The best erosion resistance for deposits formed in alkaline baths is attributed to the small thickness and crystalline structure. The results showed also that the cavitation erosion resistance is independent on surface hardness.
\end{abstract}

Keywords: Electroless Ni- P coatings; Heat treatment; Cavitation erosion

\section{Introduction}

Cavitation, a repeated formation and violent collapse of bubbles in a liquid, created by pressure changes, can result in deformation and erosion of material in the vicinity of the bubbles. Cavitation erosion is one of the main types of damage on hydraulic machinery, such as propellers, pumps, piping systems and large turbines. Some components may fail early due to cavitation, corrosion and erosion wear and cause huge economic loss. As the cavitation erosion occurs at the liquid/solid interface, it is related to surface properties rather than bulk properties, and the cavitation erosion resistance of a component may be improved by some surface engineering techniques. Surface engineering techniques have the advantage of consuming only a small amount of expensive material on the surface while using an inexpensive substrate for the bulk. Therefore, the research on surface

Corresponding author.

E-mail address: sgarrab2005@yahoo.co.uk 
1990

Effect of Heat Treatment and Bath Composition of Electroless Nickel-Plating on Cavitation Erosion Resistance, pp. 1989 - 2011

engineering techniques and coating materials are emphasized for enhancing the cavitation erosion resistance of mechanic parts in recent years [1].

Electroless plating is a chemical reduction process, including catalytic reduction of a metallic ion from an aqueous solution, and the subsequent deposition of the metal without the use of electrical energy. Electroless coatings can be divided into three main categories: (i) alloy coatings, (ii) composite coatings and (iii) metallic coatings. Mainly two types of baths have been used for depositing alloys, acidic and alkaline baths. The electroless deposition is promising to prepare durable metal films on both conducting and nonconducting substrates of different geometries. During the past five decades, electroless plating has gained popularity due to its ability to offer excellent deposition characteristics, such as uniform coverage, freedom from porosity, hardness, corrosion resistance, solderability, braze and weldability, wear resistance and lubricity [2]. Electroless nickel coatings are the more popular which possess some distinct collection of properties [3]. Electroless coatings find their use in almost every domain, from simple knitting needles to the mighty aerospace applications, with their range of applications continuously broadening.

These properties, changing with nickel and phosphorus levels in the deposit depend on the composition and $\mathrm{pH}$ of the plating bath used [4-8]. However, the advanced electroless nickel baths must meet not only plating rate but also coatings composition standards. The baths should be sufficiently stable for a long-term use by continuous replenishment with the components required. A possibility to regenerate them and easily decontaminate is an indispensable condition for the advanced electroless nickel baths $[9,10]$. This is one of the reasons why electroless nickel process has still been extensively studied.

The as-plated electroless nickel deposits has an amorphous phase structure [8]. However, heat-treatment is an important factor that affects the thickness, hardness, structure and morphology of deposit [6]. Generally acknowledged optimal heat treatment regime is $400{ }^{\circ} \mathrm{C}$ for $1 \mathrm{~h}$ as it results in maximal hardness of electroless nickel coatings. The hardness increase is attributed to the crystallization of nickel and to the precipitation of fine particles of $\mathrm{Ni}_{3} \mathrm{P}$ phase. Use of higher heat treatment temperatures and longer times leads to the progressive hardness decrease, which can be attributed to the nickel grain growth and to the phosphides coarsening. The influence of heat treatment at $400{ }^{\circ} \mathrm{C}$ for $1 \mathrm{~h}$ on both the electroless $\mathrm{Ni}-\mathrm{P}$ and composite coating in resisting cavitation erosion was examined by Lin and He [11], and Lin et al. [12]. It was found that the best cavitation erosion resistance, in either distilled water or a 3.5 wt.\% $\mathrm{NaCl}$ solution, is achieved through both the incorporation of nano-SiC particles and the application of a post-heat treatment. Lin and He [11] interpreted the improvement in cavitation erosion resistance by the increase in the film hardness and adhesion achieved by heat treatment.

A consensus has developed that material removal in multiple-impact situations (e.g., cavitation erosion, liquid-droplet erosion, and of solid-particle erosion) is not a result of single impulses or impacts. That is, damage accumulates over thousands of impacts before a particle is dislodged as discussed by Preece and Hansson [13]. Ahmed et al. [14-16] and Abouel-Kasem et al. [17-19] ran systematic observations of eroded surfaces and dislodged particles for different materials cavitated in different liquids and clearly showed that the

Journal of Engineering Sciences, Assiut University, Faculty of Engineering, Vol. 41, No. 5, September, 2013, E-mail address: jes@aun.edu.eg 
Effect of Heat Treatment and Bath Composition of Electroless Nickel-Plating on Cavitation Erosion Resistance, pp. 1989 - 2011

predominant failure mode in cavitation erosion was fatigue. The evidence of fatigue can also be deduced from the experiments of Vaidya and Preece [20], and Wade and Preece [21]. Numerically, Bedkowski et al. [22] showed that fatigue tests under random loading on cavitation erosion of steels may be described with a mathematical model of the same type. Richman and McNaughton [23] presented a good correlation between material removal rates and cyclic deformation parameters, a strong indication that damage in cavitation erosion is a fatigue process. However, it could be expected that an increase in hardness of deposits achieved as a result of heat treatment is not the controlling factors in increasing the erosion resistance.

In the present work, the cavitation erosion performance of structural steel (AISI 1045), electroless coated by Nickel-Phosphorus was investigated. The study considers the effect of plating properties such as type of bath, chemical composition in the coating process, as well as the effect of heat treatment at different temperatures.

\section{Experimental Procedures}

\subsection{Deposition of electroless $\mathrm{Ni}-\mathrm{P}$ coating}

The electroless Ni-P was deposited on AISI 1045 carbon steel flat-surfaces cylindrical specimens of of $14 \mathrm{~mm}$ in diameter and $10 \mathrm{~mm}$ height. The steel nominal composition and mechanical properties are given in Tables 1 and 2 [24], respectively. The substrate flat surfaces were carefully polished with SiC emery papers (from grades \#80 to \#1000). All the specimens were subjected to the following pre-treatment and plating procedure:

1 - Rinsing by immersion in distilled water at room temperature for $3 \mathrm{~min}$.

2-ultrasonically cleaned in acetone for 5 minutes

3 - Rinsing by immersion in distilled water at room temperature for $3 \mathrm{~min}$

4-Alkaline cleaning in $40 \% \mathrm{NaOH}$ for $30 \mathrm{sec}$.

5 - Rinsing by immersion in distilled water at room temperature for $3 \mathrm{~min}$.

6-Acid pickling in $10 \% \mathrm{HCL}(\mathrm{MW}=36-46)$ for $60 \mathrm{sec}$.

7. Rinsing by immersion in distilled water at room temperature for $3 \mathrm{~min}$.

By using inert metallic wire the samples were hanged in the plating solutions when its temperature reaches $70{ }^{\circ} \mathrm{C}$, solution stirring is carried out by magnetic stirrer with 110 RPM. After plating completed (after 60min) the samples are immediately washed thoroughly by distilled water.

The electroless deposition was carried out in two baths, acidic and alkaline. The bath was a glass vessel of $1000 \mathrm{ml}$. The chemical constituents for each solution in acidic and alkaline bath as well as experimental conditions are presented in Tables 3and 4, respectively. Acidic solutions are given codes I, II, III and IV, and alkaline solutions codes V, VI.

Journal of Engineering Sciences, Assiut University, Faculty of Engineering, Vol. 41, No. 5, September, 2013,E-mail address: jes@aun.edu.eg 
1992

Effect of Heat Treatment and Bath Composition of Electroless Nickel-Plating on Cavitation Erosion Resistance, pp. 1989 - 2011

\subsection{Post heat treatment of electroless Ni-P deposit coating}

In order to study the film properties, coated samples were thermally treated in a tube furnace under nitrogen atmosphere. The coatings were isothermally heat treated at different temperatures of $300,400,650{ }^{\circ} \mathrm{C}$ for $1 \mathrm{~h}$, then the samples were allowed to cool down in the furnace. The surface morphologies and elemental compositions of the coatings were characterized by optical microscope and X-ray energy dispersive spectrometer. The hardness of coatings and substrate was measured using an (Adolph I, Buehler, Inc) Vickers diamond indenter at a load of $100 \mathrm{~g}$ for a loading time of $20 \mathrm{~s}$. The average of five repeated measurements is reported.

Table 1.

Chemical Composition of mild steel [24]

\begin{tabular}{|l|r|r|r|r|}
\hline Carbon (C) & \multicolumn{1}{|c|}{ Silicon (Si) } & Manganese (Mn) & Phosphorus (P) & Sulphur (S) \\
\hline $0.42 \%-0.48 \%$ & $0.15 \%-0.35 \%$ & $0.3 \%-0.9 \%$ & $0.030 \%$ Max & $0.035 \%$ Max \\
\hline
\end{tabular}

Table 2.

Mechanical properties of 1045 carbon steel [24]

\begin{tabular}{|c|c|c|c|c|c|c|c|}
\hline $\begin{array}{c}\text { Density } \\
\mathbf{k g} / \mathbf{m 3}\end{array}$ & $\begin{array}{c}\text { Young's } \\
\text { Modulus } \\
\text { GPa }\end{array}$ & $\begin{array}{c}\text { Tensile } \\
\text { Strength Mpa }\end{array}$ & $\begin{array}{c}\text { Yield Strength } \\
\text { Mpa }\end{array}$ & $\begin{array}{c}\text { Elastic } \\
\text { Modulus } \\
\text { GPa }\end{array}$ & $\begin{array}{c}\text { Poisson's } \\
\text { ratio }\end{array}$ & $\begin{array}{c}\text { Brinell } \\
\text { Hardness HB }\end{array}$ & $\begin{array}{c}\text { Reduction } \\
\text { in Area } \\
(\%)\end{array}$ \\
\hline $\begin{array}{c}7700- \\
8030\end{array}$ & $190-210$ & $\begin{array}{c}569 \\
\text { Standard }\end{array}$ & $\begin{array}{c}343 \\
\text { Standard }\end{array}$ & $190-210$ & $0.27-0.30$ & $\begin{array}{c}160-220 \\
\text { Annealed }\end{array}$ & 45 \\
\hline & $\begin{array}{c}686 \\
\text { Quenching, } \\
\text { Tempering }\end{array}$ & $\begin{array}{c}490 \\
\text { Quenching, } \\
\text { Tempering }\end{array}$ & & & & \\
\hline
\end{tabular}

Table 3.

Electroless Nickel Phosphorus plating with acidic solutions

\begin{tabular}{|c|c|c|c|c|}
\hline Code no. & Chemical Name & Formula & Function & Amount \\
\hline \multirow{5}{*}{ I } & Nickel Sulfate & NiSO4- 6H2O & Nickel source & $35 \mathrm{~g} / \mathrm{L}$ \\
\hline & Sodium hypophosphite & $\mathrm{NaH} 2 \mathrm{PO} 2$ & Reducing agent & $10 \mathrm{~g} / \mathrm{L}$ \\
\hline & Sodium acetate & $\mathrm{CH} 3 \mathrm{COONa} \cdot 3 \mathrm{H} 2 \mathrm{O}$ & Adjusting $\mathrm{pH}$ & $10 \mathrm{~g} / \mathrm{L}$ \\
\hline & Temp & \multicolumn{3}{|c|}{$80-90{ }^{\circ} \mathrm{C}$} \\
\hline & $\mathrm{PH}$ & \multicolumn{3}{|c|}{5} \\
\hline \multirow{5}{*}{ II } & Nickel Sulfate & NiSO4- 6H2O & Nickel source & $15 \mathrm{~g} / \mathrm{L}$ \\
\hline & Sodium hypophosphite & $\mathrm{NaH} 2 \mathrm{PO} 2$ & Reducing agent & $14 \mathrm{~g} / \mathrm{L}$ \\
\hline & sodium acetate & $\mathrm{CH} 3 \mathrm{COONa} \cdot 3 \mathrm{H} 2 \mathrm{O}$ & Adjusting pH & $13 \mathrm{~g} / \mathrm{L}$ \\
\hline & Temp & \multicolumn{3}{|c|}{$80-90^{\circ} \mathrm{C}$} \\
\hline & $\mathrm{PH}$ & \multicolumn{3}{|c|}{$4-6$} \\
\hline
\end{tabular}

Journal of Engineering Sciences, Assiut University, Faculty of Engineering, Vol. 41, No. 5, September, 2013, E-mail address: jes@aun.edu.eg 
Effect of Heat Treatment and Bath Composition of Electroless Nickel-Plating on Cavitation Erosion Resistance, pp. 1989 - 2011

\begin{tabular}{|c|c|c|c|c|}
\hline Code no. & Chemical Name & Formula & Function & Amount \\
\hline \multirow{5}{*}{ III } & Nickel Sulfate & NiSO4- 6H2O & Nickel source & $15 \mathrm{~g} / \mathrm{L}$ \\
\hline & Sodium hypophosphite & $\mathrm{NaH} 2 \mathrm{PO} 2$ & Reducing agent & $26 \mathrm{~g} / \mathrm{L}$ \\
\hline & sodium acetate & $\mathrm{CH} 3 \mathrm{COONa} \cdot 3 \mathrm{H} 2 \mathrm{O}$ & adjusting $\mathrm{pH}$ & $13 \mathrm{~g} / \mathrm{L}$ \\
\hline & Temp & \multicolumn{3}{|c|}{$80-90^{\circ} \mathrm{C}$} \\
\hline & $\mathrm{PH}$ & \multicolumn{3}{|c|}{5} \\
\hline \multirow{6}{*}{ IV } & Nickel Sulfate & NiSO4- 6H2O & Nickel source & $17 \mathrm{~g} / \mathrm{L}$ \\
\hline & Sodium hypophosphite & $\mathrm{NaH} 2 \mathrm{PO} 2$ & Reducing agent & $15 \mathrm{~g} / \mathrm{L}$ \\
\hline & Sodium acetate & $\mathrm{CH} 3 \mathrm{COONa} \cdot 3 \mathrm{H} 2 \mathrm{O}$ & Adjusting $\mathrm{pH}$ & $12 \mathrm{~g} / \mathrm{L}$ \\
\hline & Sodium citrate & $\mathrm{Na} 3 \mathrm{C} 6 \mathrm{H} 5 \mathrm{O} 7-2 \mathrm{H} 2 \mathrm{O}$ & Complexing agent & 10 \\
\hline & Temp & \multicolumn{3}{|c|}{$80-90^{\circ} \mathrm{C}$} \\
\hline & $\mathrm{PH}$ & \multicolumn{3}{|c|}{6.5} \\
\hline
\end{tabular}

Table 4.

Electroless Nickel Phosphorus plating with alkaline solutions

\begin{tabular}{|c|c|c|c|c|}
\hline Code no. & Chemical Name & Formula & Function & Amount \\
\hline \multirow{5}{*}{$\mathbf{V}$} & Nickel chloride & $\mathrm{NiC} 12-6 \mathrm{H} 2 \mathrm{O}$ & Nickel source & $35 \mathrm{~g} / \mathrm{L}$ \\
\hline & Sodium hypophosphite & $\mathrm{NaH} 2 \mathrm{PO} 2$ & Reducing agent & $10 \mathrm{~g} / \mathrm{L}$ \\
\hline & Ammonium chloride & NH4C1 & adjusting $\mathrm{pH}$ & $100 \mathrm{~g} / \mathrm{L}$ \\
\hline & Temp & \multicolumn{3}{|c|}{$80-90^{\circ} \mathrm{C}$} \\
\hline & $\mathrm{PH}$ & \multicolumn{3}{|c|}{$8-9$} \\
\hline \multirow{6}{*}{ VI } & Nickel Sulfate & NiSO4- 6H2O & Nickel source & $40 \mathrm{~g} / \mathrm{L}$ \\
\hline & Sodium hypophosphite & $\mathrm{NaH} 2 \mathrm{PO} 2$ & Reducing agent & $10 \mathrm{~g} / \mathrm{L}$ \\
\hline & Ammonium chloride & NH4C1 & Adjusting pH & $50 \mathrm{~g} / \mathrm{L}$ \\
\hline & Sodium citrate & $\mathrm{Na} 3 \mathrm{C} 6 \mathrm{H} 5 \mathrm{O} 7-2 \mathrm{H} 2 \mathrm{O}$ & Complexing agent & 80 \\
\hline & Temp & \multicolumn{3}{|c|}{$80-90^{\circ} \mathrm{C}$} \\
\hline & $\mathrm{PH}$ & \multicolumn{3}{|c|}{$8-9$} \\
\hline
\end{tabular}

\subsection{Vibratory cavitation erosion testing}

Cavitation erosion experiments were carried out in an ultrasonic induced cavitation facility with A $550 \mathrm{~W}$ ultrasonic probe, shown schematically in Fig.1. The vibratory frequency and peak-to-peak amplitude used were $19.5 \pm 0.5 \mathrm{KHz}$ and $50 \mu \mathrm{m}$, respectively. The specimen was placed co-axially with the horn-tip and was held stationary at the distance $\mathrm{L}$ from the horn tip as shown in Fig.1. The separation distance L between the stationary specimen and the horn tip was initially adjusted using a dial gage and maintained at a value of $0.8 \mathrm{~mm}$, in the present study, to obtain significant value of erosion rate [25]. This experiment procedure is confirming to ASTM standard G32-09 [26]. The horn-tip is flat with $12.7 \mathrm{~mm}$ diameter and stationery specimen has a diameter of $14 \mathrm{~mm}$ before coating.

Journal of Engineering Sciences, Assiut University, Faculty of Engineering, Vol. 41, No. 5, September, 2013,E-mail address: jes@aun.edu.eg 
1994

Effect of Heat Treatment and Bath Composition of Electroless Nickel-Plating on Cavitation Erosion Resistance, pp. 1989 - 2011

The specimen and the end of the stepped horn was immersed in $1200 \mathrm{ml}$ open beaker having $700 \mathrm{ml}$ of test liquid. Since the test liquid temperature markedly affects the degree of erosion [16,27], the test liquid temperature in the beaker was kept constant at $27 \pm 1{ }^{\circ} \mathrm{C}$ by circulating cooling water around the beaker, as shown in figure1. Preliminary tests showed that temperature of the liquid film on the specimen surface rose rapidly regardless of the constant temperature in the beaker. This temperature was measured for a maximum duration test time with thermocouple inserted in the centre of test piece. It was found for 10 min.(maximum interval test time), that the film temperature did not exceed the controlled temperature of beaker by more than $2^{\circ} \mathrm{C}$. Test specimen was removed after every time interval and washed

in acetone with an ultrasonic cleaner and the erosion mass was measured with a precision balance having a sensitivity of $0.01 \mathrm{mg}$.

In this study electroless nickel deposits with various bath process parameters have been prepared. The objective of this paper is to investigate cavitation erosion resistance for the electroless nickel deposits undergoing different heat treatments. Since both bath process parameters and heat treatment variation lead to structural modifications of the Ni-P coatings, the cavitation erosion data are discussed in the light of X-ray diffraction (XRD), microhardness, optical microscope, and weight loss results.

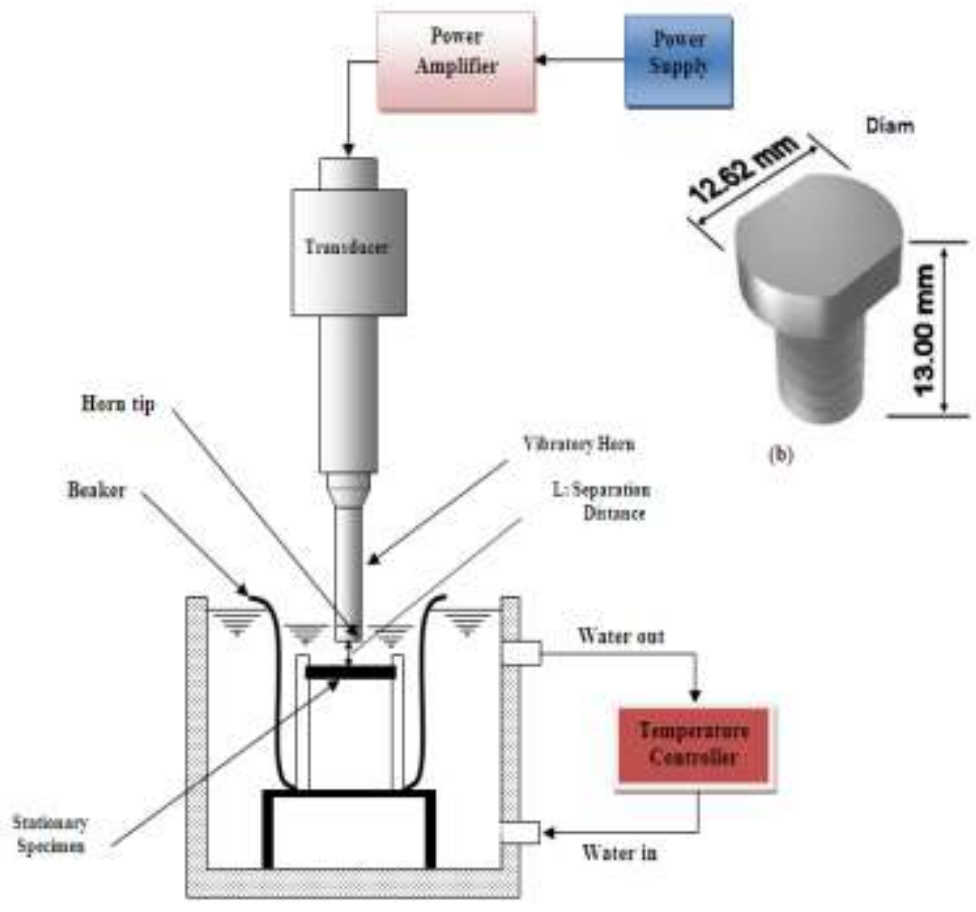

(a)

Fig. 1. Schematic view of test apparatus (a) and Horn's disc (b)

Journal of Engineering Sciences, Assiut University, Faculty of Engineering, Vol. 41, No. 5, September, 2013,E-mail address: jes@aun.edu.eg 
Effect of Heat Treatment and Bath Composition of Electroless Nickel-Plating on Cavitation Erosion Resistance, pp. 1989 - 2011

\section{Results and discussion}

\subsection{Coating surface morphology}

Figure 2 shows the optical images of the surface morphologies of electroless Ni-P coating for various solutions before and after heat treatment. The deposited surface morphology before heat treatment reveals that all the electroless Ni-P deposits are uniform and continuous and there were no obvious flaws or apertures on the coating surface. Also, all deposit surfaces are smooth which suggest the highly protectiveness of the Ni-P coating. It can be also seen from the as-deposited surfaces that there is no remarkable difference with the change in solutions. For heat treating at temperature of $300{ }^{\circ} \mathrm{C}$ and 400 ${ }^{\circ} \mathrm{C}$, it can be seen that the surface morphology changes are not obvious. However, for heat treatment at $650{ }^{\circ} \mathrm{C}$

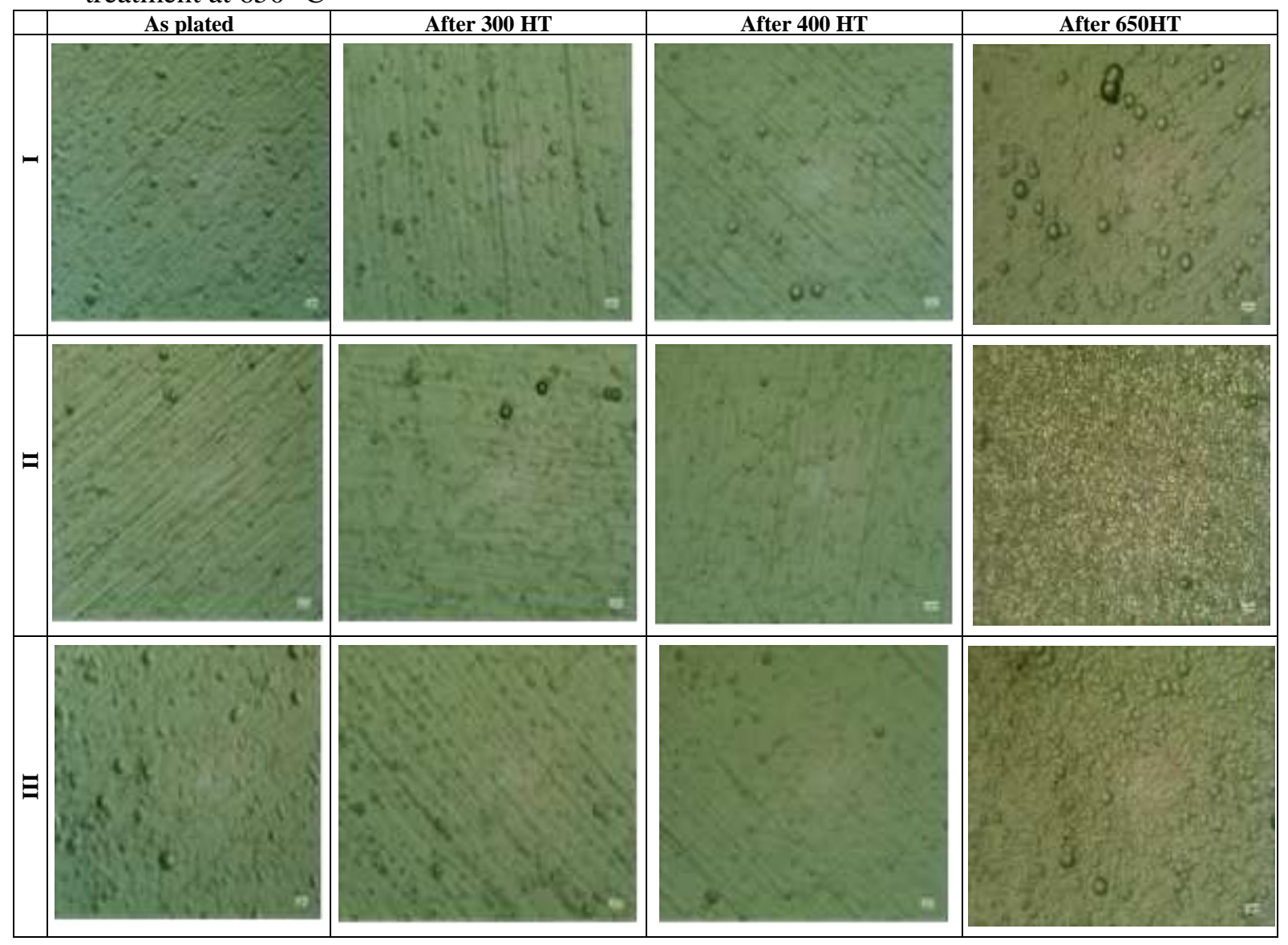

Journal of Engineering Sciences, Assiut University, Faculty of Engineering, Vol. 41, No. 5, September, 2013,E-mail address: jes@aun.edu.eg 
1996

Effect of Heat Treatment and Bath Composition of Electroless Nickel-Plating on Cavitation Erosion Resistance, pp. 1989 - 2011

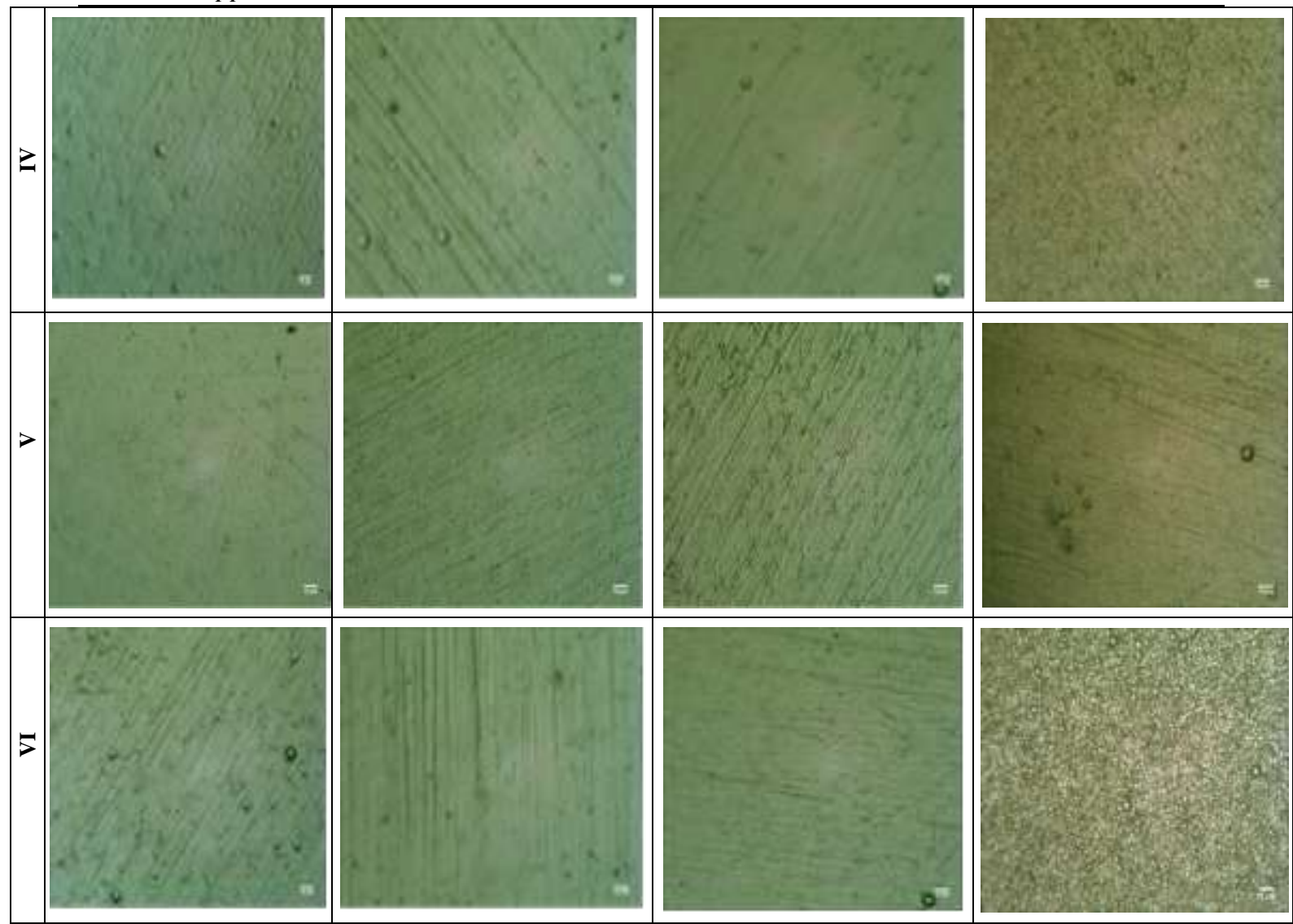

Fig.2. Optical microscope photos representing surface morphology of the electroless Ni-P alloy deposits obtained before and after heat treatment

the surface morphology shows a discernible changes, where a clear crystalline structure appears. This has been observed in many works [e.g. 28-30]. The Rabizadeh et al. [28] made a scan analysis of Ni-P coating heat treated at $600{ }^{\circ} \mathrm{C}$ (for $15 \mathrm{~min}$ ). Their results show a formation of an inter-diffusional layer and its elemental distribution that affects the coating properties. They explained the difference in the effect of heat treatment at different temperatures as follows; atoms under low temperature heat treatment (below $400^{\circ} \mathrm{C}$ ) can have short-range movement which is called structural relaxation such as annihilation of point defects and dislocations within grains and grain boundary zones rather than long range diffusion. The higher the temperature, the greater the atomic vibration energy. As the heat treatment temperature increases, more vacancies are present and more thermal energy is available, and so the diffusion rate is higher at higher temperatures. Hence, Production of an inter-diffusional layer, formed as a result of inter-diffusion of nickel and phosphorous from the coating to the substrate and iron in the reverse direction from the substrate will develop upon heating at $600^{\circ} \mathrm{C}$.

Journal of Engineering Sciences, Assiut University, Faculty of Engineering, Vol. 41, No. 5, September, 2013, E-mail address: jes@aun.edu.eg 
Effect of Heat Treatment and Bath Composition of Electroless Nickel-Plating on Cavitation Erosion Resistance, pp. 1989 - 2011

The deposit thickness for each solution was determined from optical micrographs of the metallographic cross-sections for the electroless coating at $1 \mathrm{~h}$ and heat treatment at 400 ${ }^{\circ} \mathrm{C}$ as shown in the Figure 3. The thickness value is given in Table 5. The results indicate that the deposit thickness for alkaline solutions is smaller than that for acidic solutions.

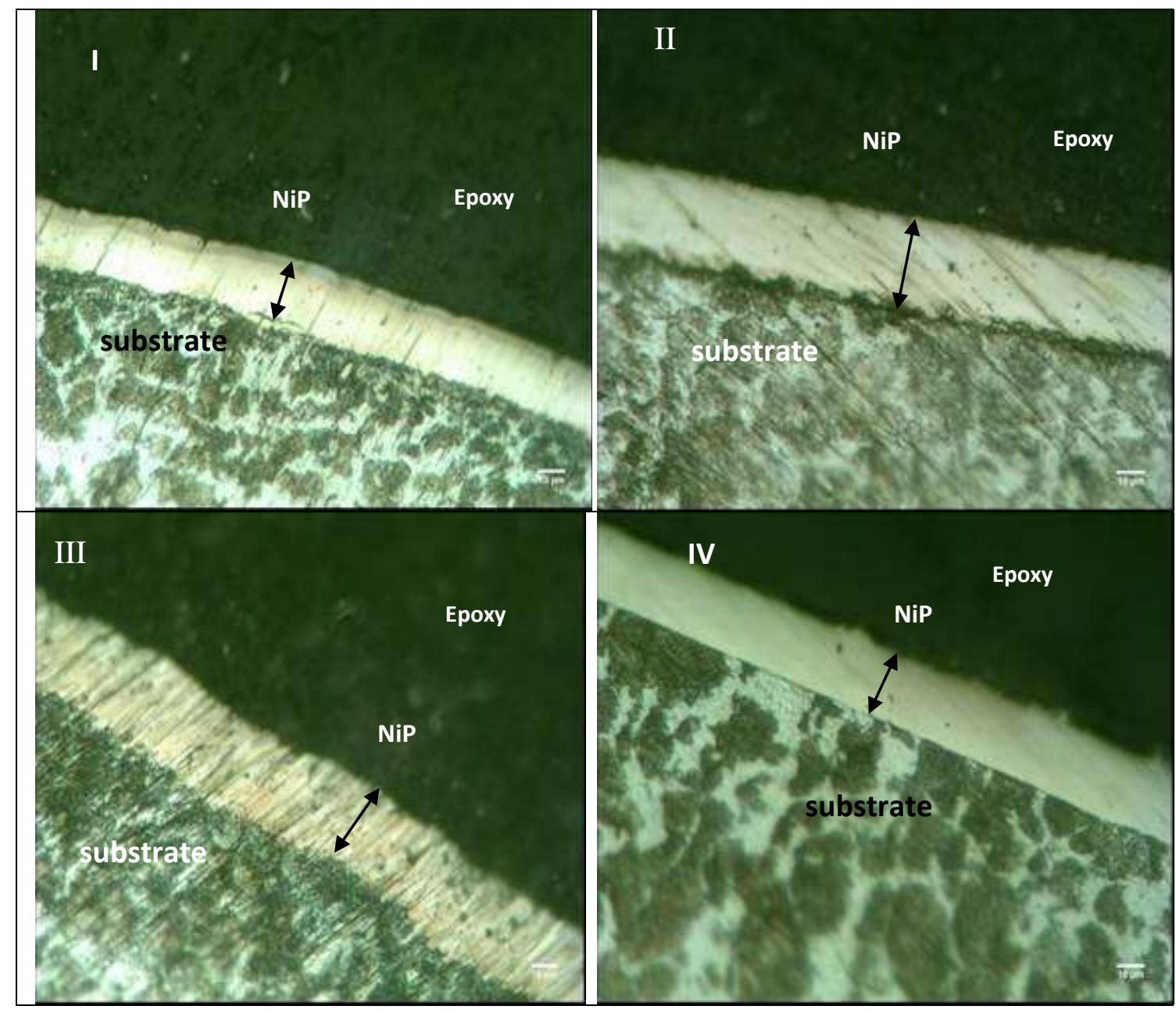

Journal of Engineering Sciences, Assiut University, Faculty of Engineering, Vol. 41, No. 5, September, 2013,E-mail address: jes@aun.edu.eg 
1998

Effect of Heat Treatment and Bath Composition of Electroless Nickel-Plating on Cavitation Erosion Resistance, pp. 1989 - 2011

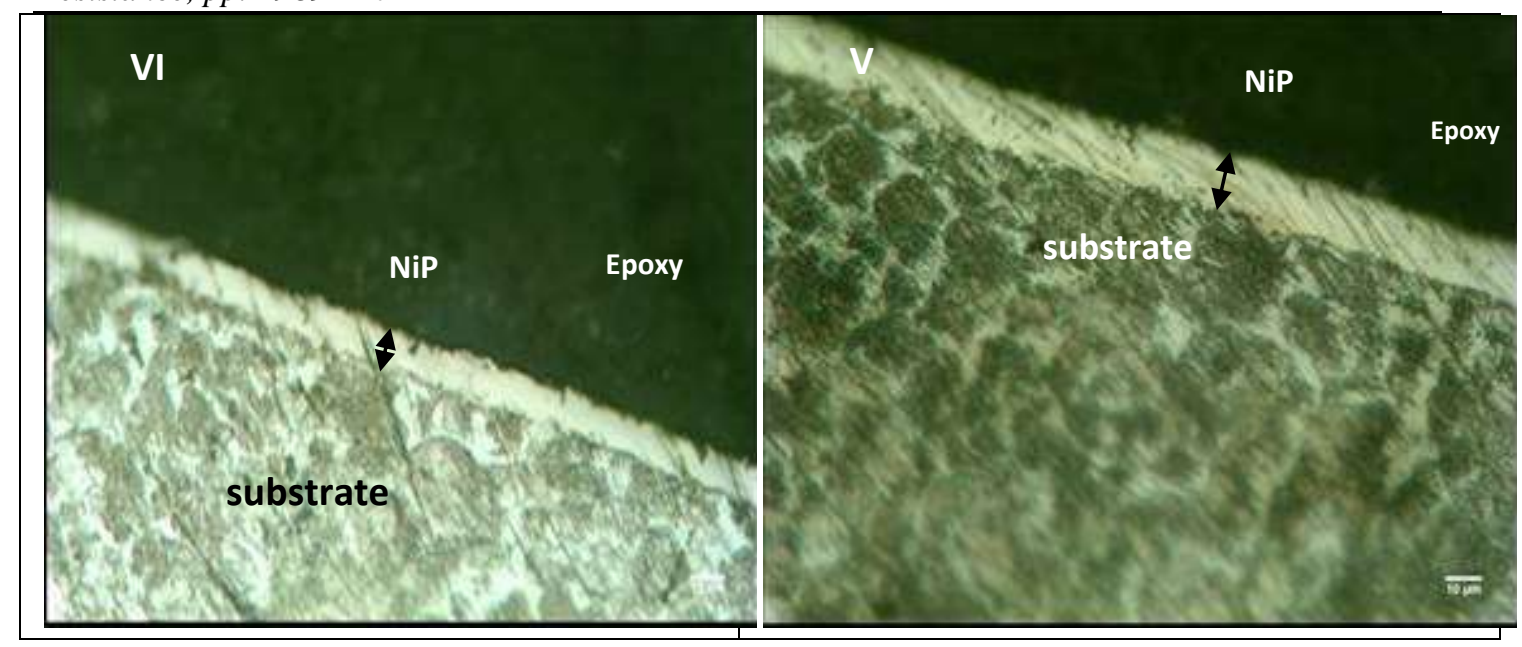

Fig. .3. Cross-sectional micrograph of the ENi-P deposits plated with different solutions

Table 5.

Film Thickness

\begin{tabular}{|c|c|}
\hline Solution code & Film thickness in $\mu \mathrm{m}$ \\
\hline I & $30-32$ \\
\hline II & $28-30$ \\
\hline III & $25-28$ \\
\hline IV & $22-25$ \\
\hline V & $18-20$ \\
\hline VI & $10-12$ \\
\hline
\end{tabular}

\subsection{X-ray diffraction analysis}

Figure 4 shows the X-ray diffraction (XRD) patterns of electroless Ni-P coatings of as plated and post heat treated films at different temperatures for different solutions. As shown in the figure, the XRD patterns of the as-plated sample before heat treatment revealed a single peak at $2 \theta=45^{\circ}$. However, the profiles of Ni-P deposit from alkaline solutions, figure 4 ( $\mathrm{V}$ and VI) depict a sharp peak and that from acidic solutions show a broad peak as shown in Fig. 4(I - IV). This proves that the structure Ni-P deposit was crystalline for alkaline solutions and amorphous for acidic solutions. It is well known that the ratio of crystalline and amorphous phases in Ni-P coatings is controlled by the phosphorus content. The phosphorus content of the coating for various plating solutions is determined using SEM/EDX analysis and is shown in Table 6. If phosphorus content is increased the crystalline phase is converted to an amorphous one [7]. The Ni-P deposits are usually divided into three alloy categories, depending on their P content: low (up to $5 \mathrm{wt}$ $\%$ ), medium (5-8 wt \%), and high (more than 9 wt \%). Deposits with low contents of P can

Journal of Engineering Sciences, Assiut University, Faculty of Engineering, Vol. 41, No. 5, September, 2013, E-mail address: jes@aun.edu.eg 
Effect of Heat Treatment and Bath Composition of Electroless Nickel-Plating on Cavitation Erosion Resistance, pp. 1989 - 2011

be characterized as crystalline and high $\mathrm{P}$ contents as amorphous [9]. This classification is rather conditional and it can be confirmed by XRD data in figure 4 .

Table 6.

Phosphorus content of various deposits

\begin{tabular}{|c|c|}
\hline Solution code & Phosphorus content, wt.\%P \\
\hline I & 3.95 \\
\hline II & 6.8 \\
\hline III & 5.49 \\
\hline IV & 8.13 \\
\hline V & 1.37 \\
\hline VI & 7.61 \\
\hline
\end{tabular}

When Ni-P deposits are heat-treated for $1 \mathrm{hr}$ at $300^{\circ} \mathrm{C}, 400^{\circ} \mathrm{C}, 650^{\circ} \mathrm{C}$, their structure undergo modification as shown in figure 4 . It can be seen from the XRD patterns at 300 ${ }^{\circ} \mathrm{C}$ that the Ni-P deposit began to crystallize, that can be inferred from the emergence of new peaks, but it depends upon solution. When the heat treatment temperature was increased to $400{ }^{\circ} \mathrm{C}$, new XRD peaks corresponding to crystalline fcc $\mathrm{Ni}$ and $\mathrm{Ni}_{\mathrm{x}} \mathrm{P}_{\mathrm{y}}$ appeared, indicating that the second phase precipitation was initiated. At this temperature, the diffraction peaks corresponding to the metastable $\mathrm{Ni}_{12} \mathrm{P}_{5}$, fcc nickel and stable $\mathrm{Ni}_{3} \mathrm{P}$ phases in the XRD profile can be seen. At $650{ }^{\circ} \mathrm{C}$ the fcc $\mathrm{Ni}$ and $\mathrm{Ni}_{3} \mathrm{P}$ peaks intensities increased with the heat treatment temperature.

Heat treatment of the as-deposited coatings causes a transformation from a supersaturated solid solution of phosphorus in nickel to a nickel matrix plus $\mathrm{Ni}_{3} \mathrm{P}$ [31]. It has been reported that different heating conditions also have shown significant influence on both the microstructural properties and crystallization behaviors of the electroless Ni-P deposits [32]. As a result of solid -state diffusion, the structures will revert to the thermodynamically most stable state. The amorphous deposits undergo a crystal growth process, and such heat treatment results in a mixture of relatively coarse-grained metallic nickel together with intermetallic phase.

Journal of Engineering Sciences, Assiut University, Faculty of Engineering, Vol. 41, No. 5, September, 2013,E-mail address: jes@aun.edu.eg 
Effect of Heat Treatment and Bath Composition of Electroless Nickel-Plating on Cavitation Erosion Resistance, pp. $1989-2011$

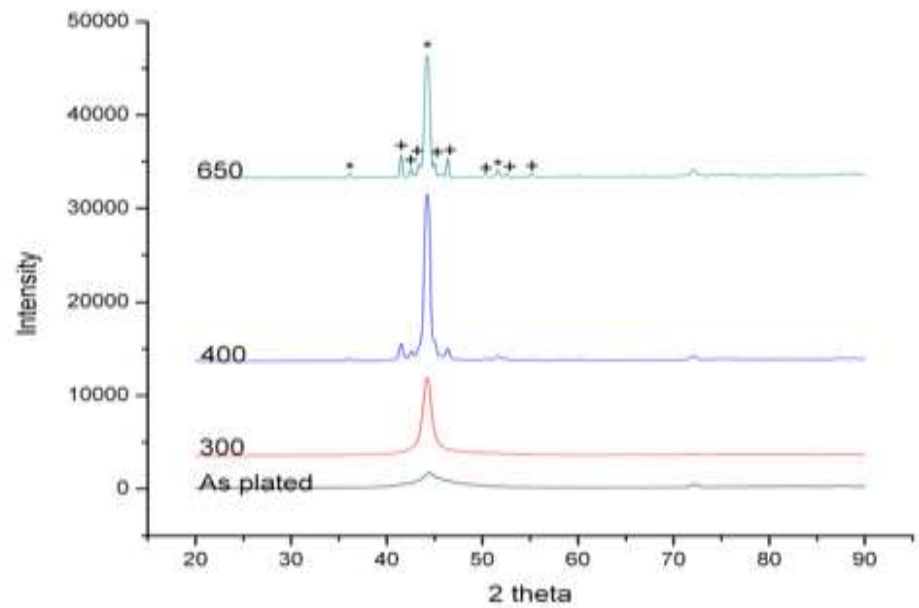

(1)

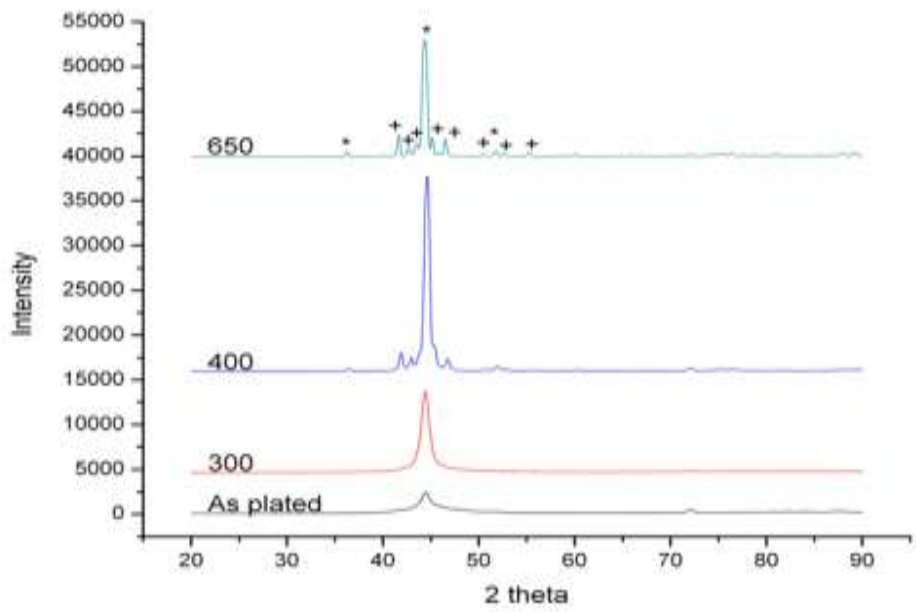

(2)

Journal of Engineering Sciences, Assiut University, Faculty of Engineering, Vol. 41, No. 5, September, 2013, E-mail address: jes@aun.edu.eg 
Effect of Heat Treatment and Bath Composition of Electroless Nickel-Plating on Cavitation Erosion Resistance, pp. 1989 - 2011

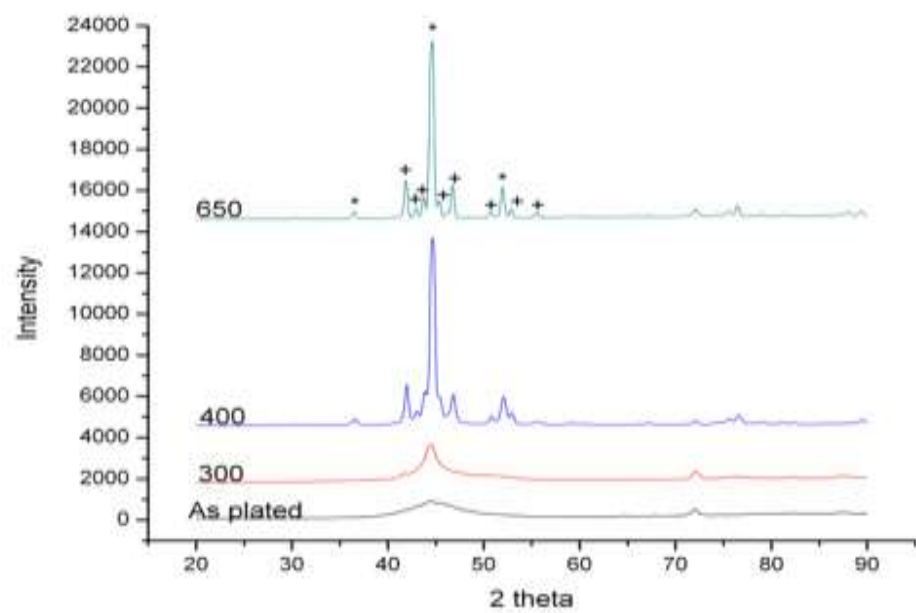

(3)

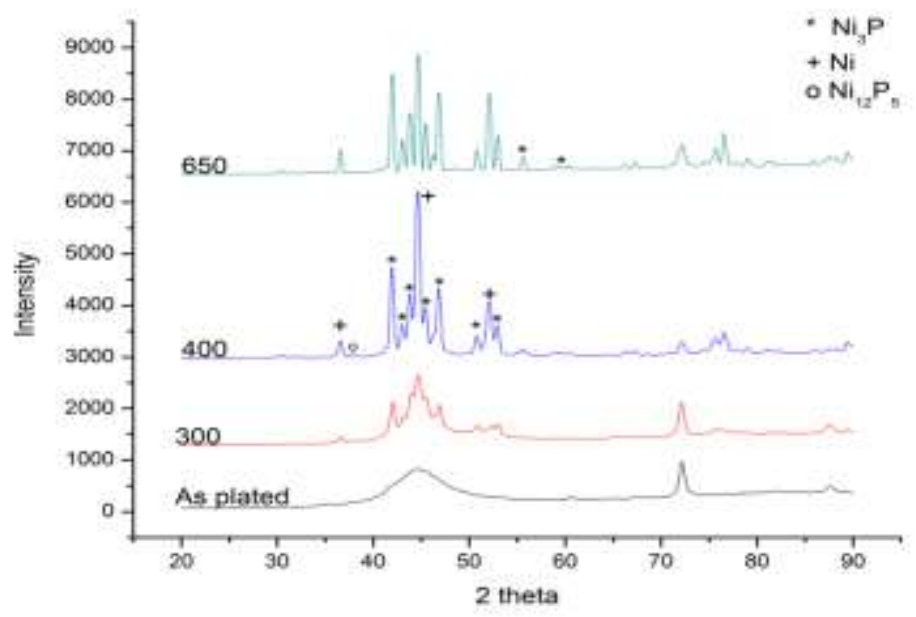

(4)

Journal of Engineering Sciences, Assiut University, Faculty of Engineering, Vol. 41, No. 5, September, 2013, E-mail address: jes@aun.edu.eg 


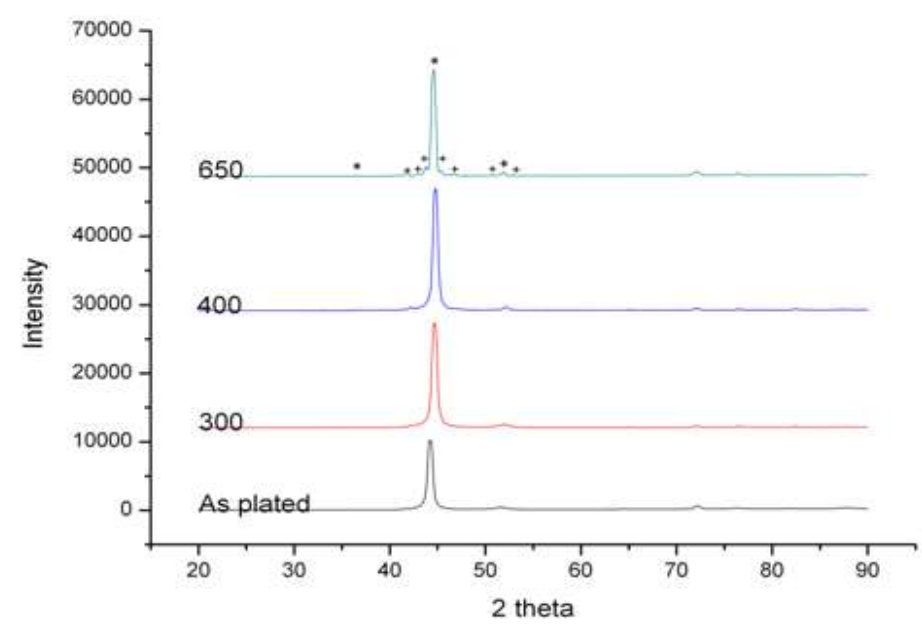

(5)

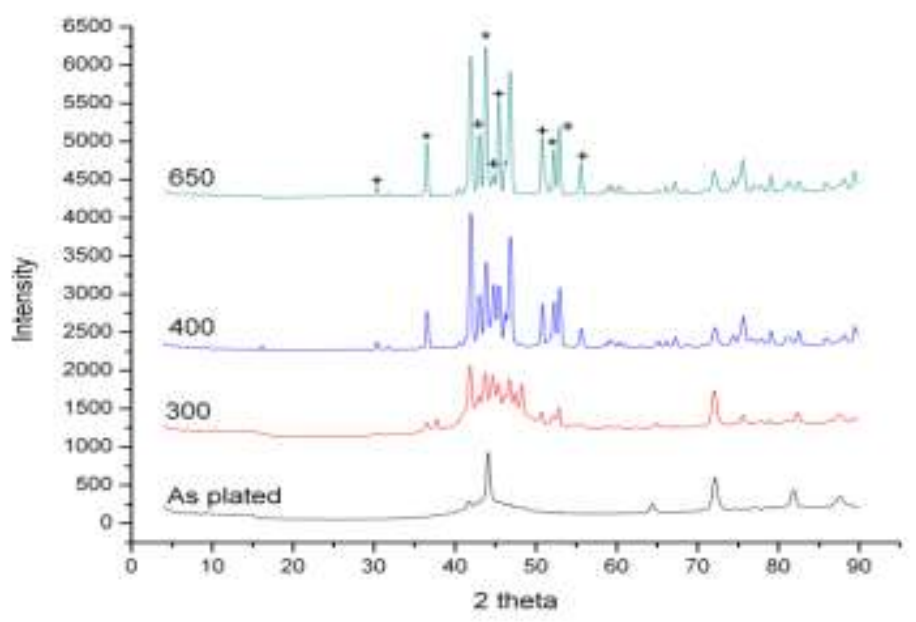

(6)

Fig. 4. Representing XRD spectra of electroless Ni-P films plated with solution codes (I, II, III ,IV, V, and VI).

\subsection{Hardness of coating}

Figure 5 shows the results obtained from the microhardness measurements performed on the samples under investigation. As generally observed, due to the thermally induced Journal of Engineering Sciences, Assiut University, Faculty of Engineering, Vol. 41, No. 5, September, 2013,E-mail address: jes@aun.edu.eg 
Effect of Heat Treatment and Bath Composition of Electroless Nickel-Plating on Cavitation Erosion Resistance, pp. 1989 - 2011

microstructural changes shown from XRD patterns in figure 4 , heat treatment had a pronounced influence on the hardness value compared with the value corresponding to the as-deposited state. However, this influence differs with the solution and temperature. Results show that the maximum hardness are either at $300{ }^{\circ} \mathrm{C}$ or at $400{ }^{\circ} \mathrm{C}$ depending on the solution. The results also show that the maximum hardness in the case of acidic solutions is greater than in alkaline solutions. This may be due to the fact that as-deposit in alkaline have a crystalline structure. As the temperature increases over $400{ }^{\circ} \mathrm{C}$, the hardness drops dramatically. Many researchers reported similar results [e.g.33-35]. The hardness increase is attributed to the crystallization of nickel and to the precipitation of fine particles of $\mathrm{Ni}_{3} \mathrm{P}$ phase. Use of higher heat treatment temperatures and longer times lead to the progressive hardness decrease, which can be attributed to the nickel grain growth and to the phosphides coarsening [36].

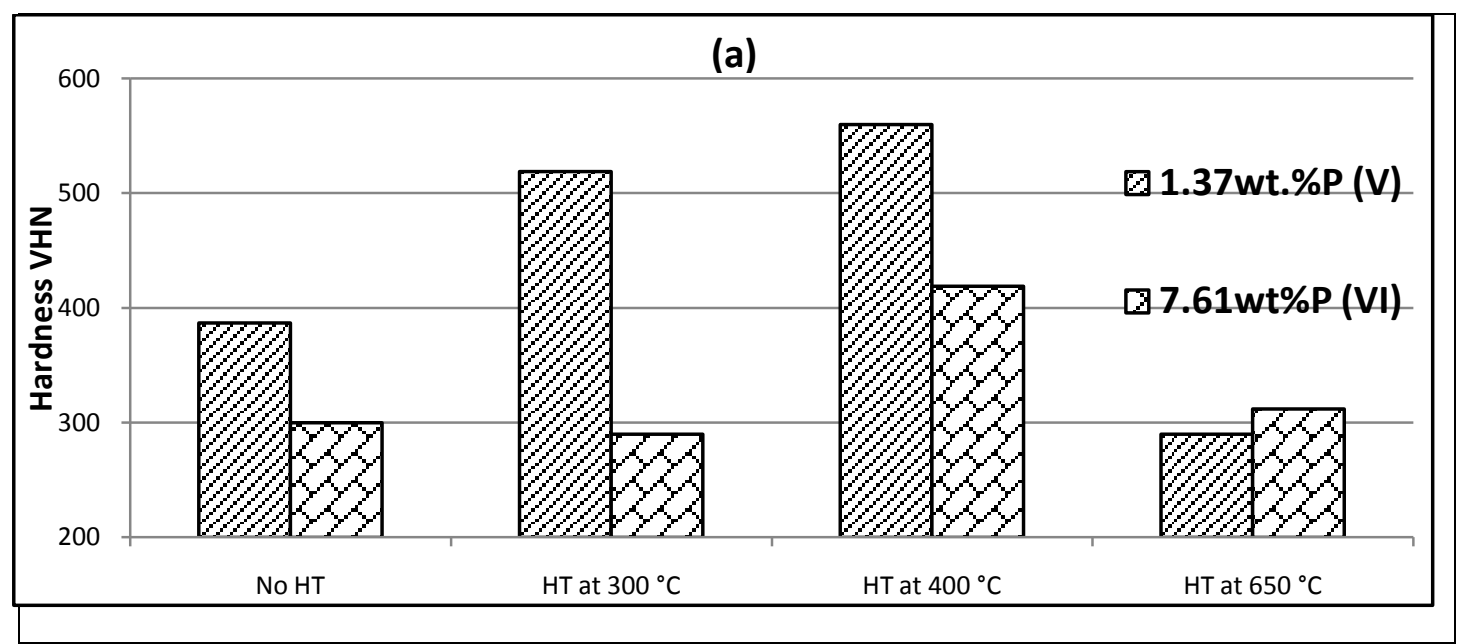

Journal of Engineering Sciences, Assiut University, Faculty of Engineering, Vol. 41, No. 5, September, 2013,E-mail address: jes@aun.edu.eg 


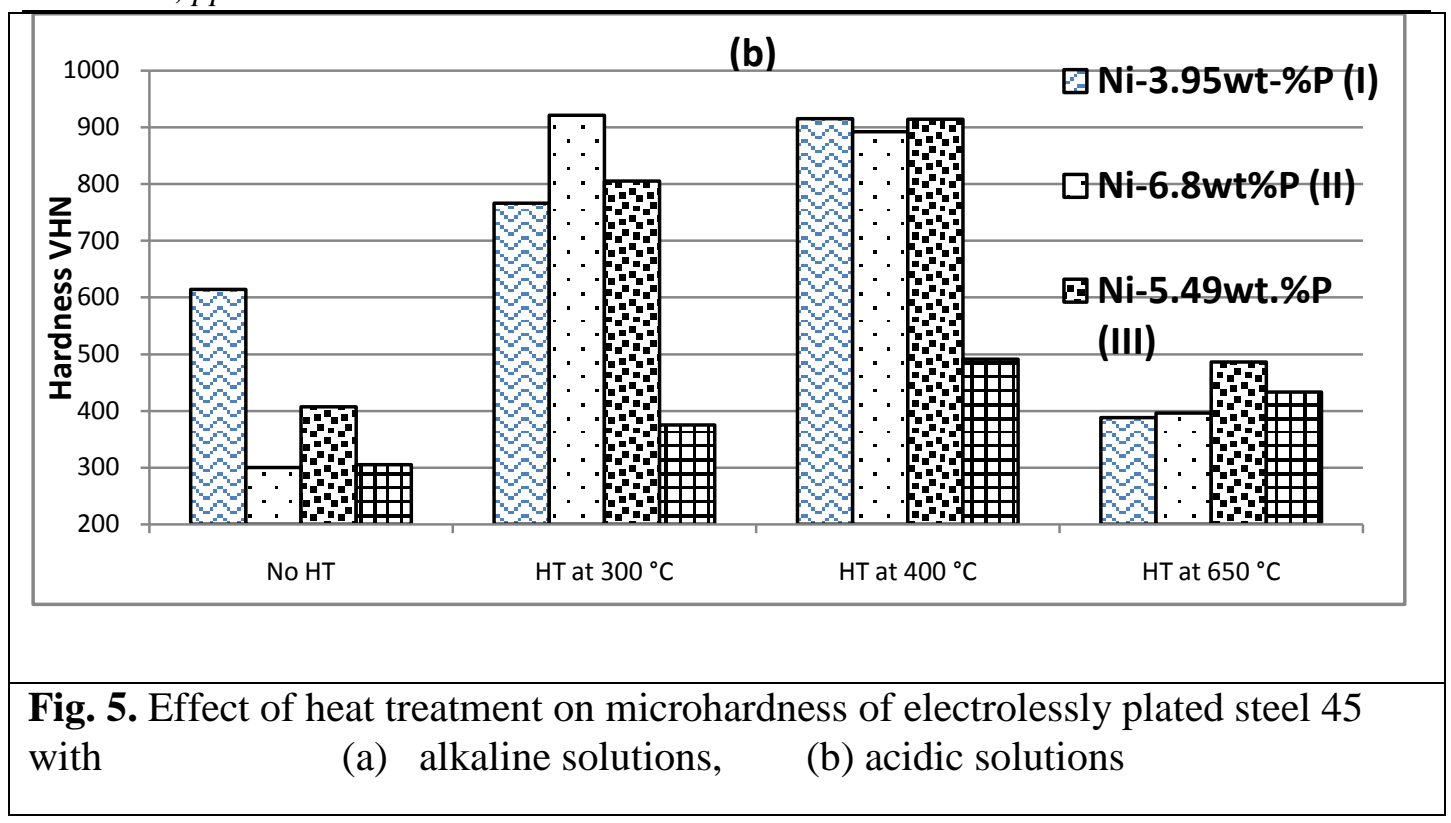

\subsection{Cavitation erosion results}

The cumulative weight loss is measured for substrate samples and others coated under the influence of various parameters, which include the type of bath, heat treatment temperature and plating solution composition. The results are shown in Fig. 6(a- f). It is worth noting that the scale of coordinate of cumulative weight loss is not the same. By comparing the weight losses of substrate and that of as-deposited and that of post heat treated deposits at different temperatures, it can be seen that the weight losses of asdeposits are the higher and that for post heat treatment deposits are the lower for all solutions. This means that the results show that the effects of interest on weight loss (as measure of cavitation erosion resistance) are heat treatment and the type of bath. The Post heat treated deposit at $650{ }^{\circ} \mathrm{C}$ from alkaline bath (solution codes V and VI) shown in Fig. 6 ( $a$ and $b$ ) was the highest erosion resistance. This is attributed to the microstructure of the coatings developed in alkaline bath that were crystalline in as-deposited and developing of crystallization after heat treatments as illustrated in Sec. 3.2. Another reason for increasing the resistance of alkaline coatings to erosion is the thickness of coatings, where it was smaller when compared to that of acidic bath. Berrios et al. [37] got a similar result. They studied the effect of the thickness of an electroless Ni-P deposit on the mechanical properties of AISI 1045plain carbon steel and they found that as the thickness deposit increases the fatigue life is reduced. On the other hand, Hsu et al. [38] studied the effect of thickness of electroless Ni-P deposit on corrosion fatigue damage of 7075-T6 Al-alloy under salt spray atmosphere. They observed that the reduction in the fatigue strength is less or to none for the thicker coating system. Their conclusion was that balancing between the need for the corrosion resistance and the fact on the fatigue strength reduction, the

Journal of Engineering Sciences, Assiut University, Faculty of Engineering, Vol. 41, No. 5, September, 2013, E-mail address: jes@aun.edu.eg 
Effect of Heat Treatment and Bath Composition of Electroless Nickel-Plating on Cavitation Erosion Resistance, pp. 1989 - 2011

optimum coating thickness seems to be greater than $5 \mu \mathrm{m}$ but less than $25 \mu \mathrm{m}$ for the aerospace alloy 7075-T6 Al-alloy.

It is reported in the literature [35] that one of the unique characteristics of electroless nickel deposition after a PHT is the superior wear resistance of the coatings. The enhancement in the wear resistance is attributed to the achievement maximum hardness of PHT coatings. Generally optimal heat treatment regime is $400{ }^{\circ} \mathrm{C}$ for $1 \mathrm{~h}$ as it results in maximal hardness of electroless nickel coatings. It is also reported [36] that annealing at temperature other than $400{ }^{\circ} \mathrm{C}$ adversely affects the wear performance of electroless nickel coatings. This may be attributed to the formation of inter-metallic phases that reduces the coating adherence to the substrate. The results, in this work, show that the maximum hardness is obtained at $300{ }^{\circ} \mathrm{C}$ or at $400{ }^{\circ} \mathrm{C}$ depending on the solution. However, the best erosion resistance enhancement was obtained for Post heat treated deposits at temperature of $650{ }^{\circ} \mathrm{C}$, except one deposit that formed in acid solution, I, was at $400{ }^{\circ} \mathrm{C}$. This means that cavitation erosion resistance does not depend on hardness. This is supported by the finding that the hardness of post heat treated coatings formed in acidic solutions is greater than those in alkaline solutions; $900 \mathrm{VHN}_{100}$ compared to $500 \mathrm{VHN}_{100}$ while the best cavitation erosion resistance was for alkaline coatings. This is in agreement with that reported in the literature [24] that there is no correlation between cavitation erosion resistance and material property or combined of properties.

\section{Conclusions}

The cavitation erosion, microhardness, microstructure and thickness of electroless Ni-P deposited on AISI 1045 carbon steel at alkaline and acidic baths for $1 \mathrm{~h}$ at different conditions are investigated. The conclusions may be summarized as follows;

1. The cavitation erosion resistance depends on bath type, deposit heat treatment temperature and plating solution composition.

2. The as-deposited coatings are the worst with respect to erosion resistance.

3. The alkaline bath gives the smaller deposit thickness and the best cavitation erosion resistance which increased three-fold compared to substrate at the same test duration of $1 \mathrm{~h}$. The enhancement in the erosion resistance for alkaline bath deposit may also be due to microstructure which was crystalline structure asdeposited

4. The results show that the erosion resistance does not depend on hardness, which has maximum value after heat treatment at temperature of $300{ }^{\circ} \mathrm{C}$ or $400{ }^{\circ} \mathrm{C}$ depending on the solution. The erosion resistance is the best at heat treatment temperature of $650{ }^{\circ} \mathrm{C}$ at which the hardness is the least.

Journal of Engineering Sciences, Assiut University, Faculty of Engineering, Vol. 41, No. 5, September, 2013,E-mail address: jes@aun.edu.eg 
Effect of Heat Treatment and Bath Composition of Electroless Nickel-Plating on Cavitation Erosion Resistance, pp. $1989-2011$
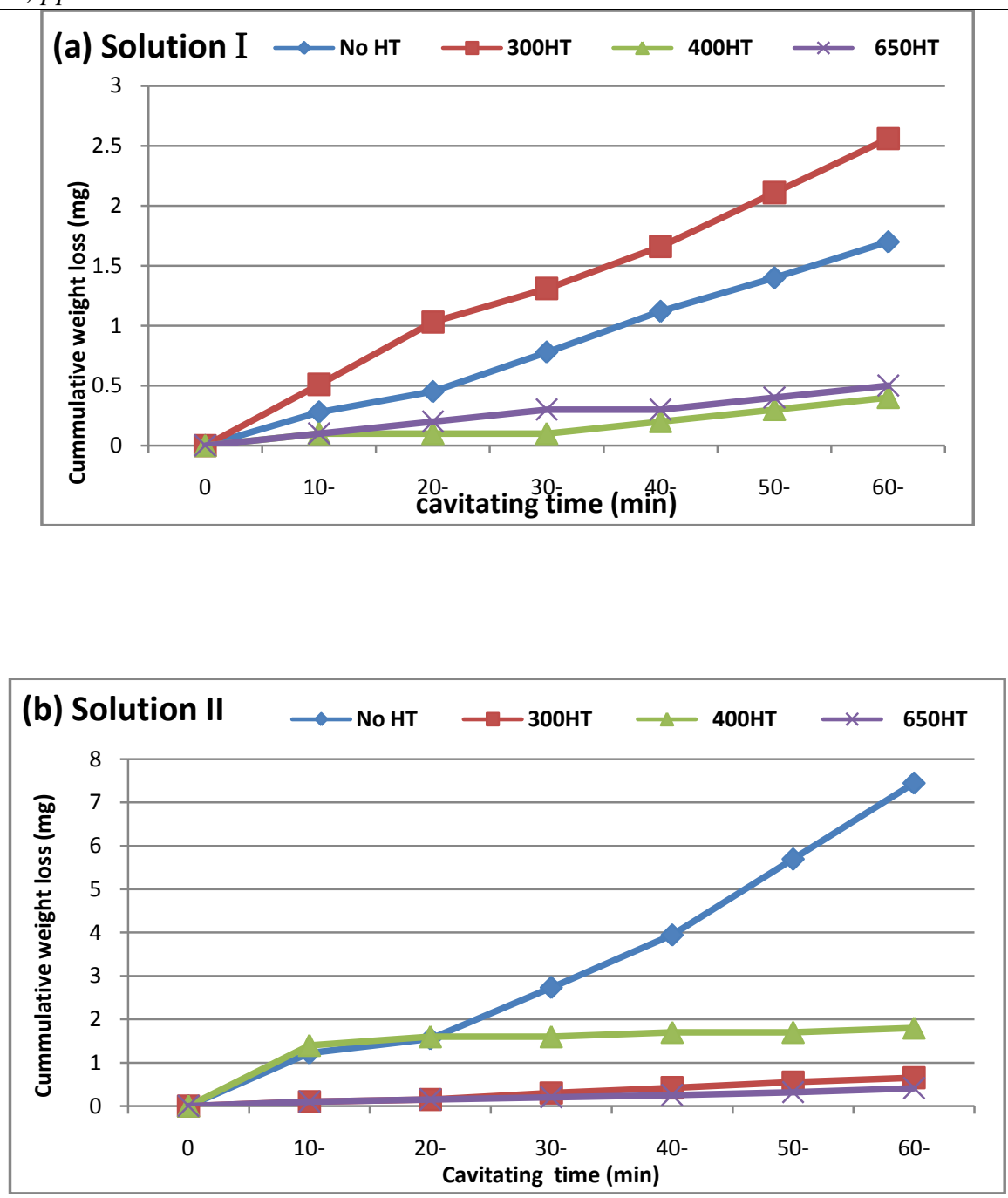

Journal of Engineering Sciences, Assiut University, Faculty of Engineering, Vol. 41, No. 5, September, 2013, E-mail address: jes@aun.edu.eg 
Effect of Heat Treatment and Bath Composition of Electroless Nickel-Plating on Cavitation Erosion Resistance, pp. 1989 - 2011

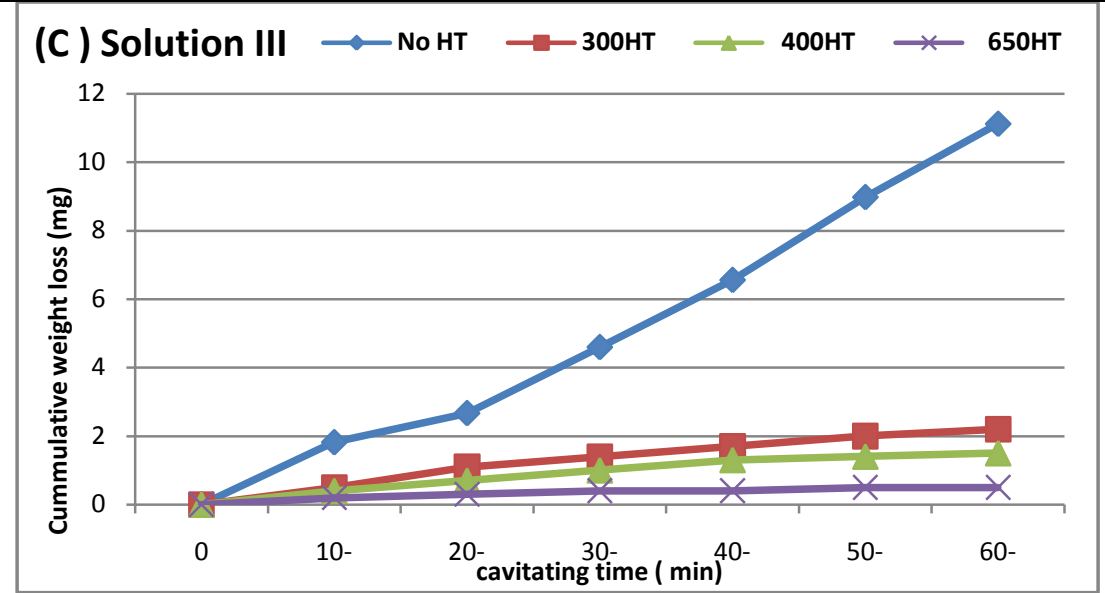

Fig. 6. ( a-f ) Effect of Heat Treatment on cumulative weight loss of ENi-P plated with different plating solutions on steel 45 substrate

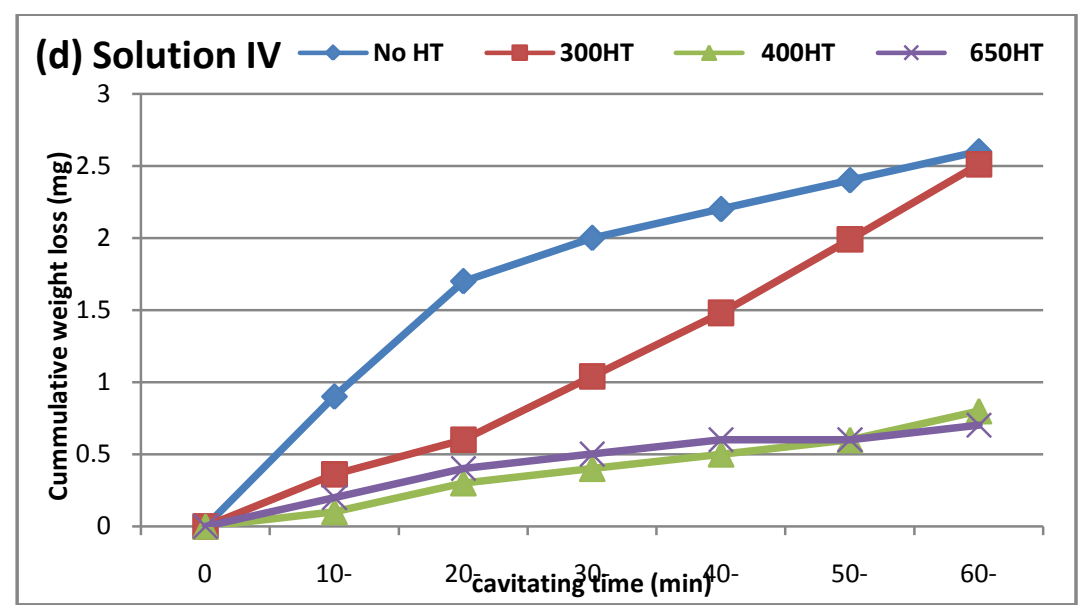

Journal of Engineering Sciences, Assiut University, Faculty of Engineering, Vol. 41, No. 5, September, 2013, E-mail address: jes@aun.edu.eg 
Effect of Heat Treatment and Bath Composition of Electroless Nickel-Plating on Cavitation Erosion Resistance, pp. 1989 - 2011
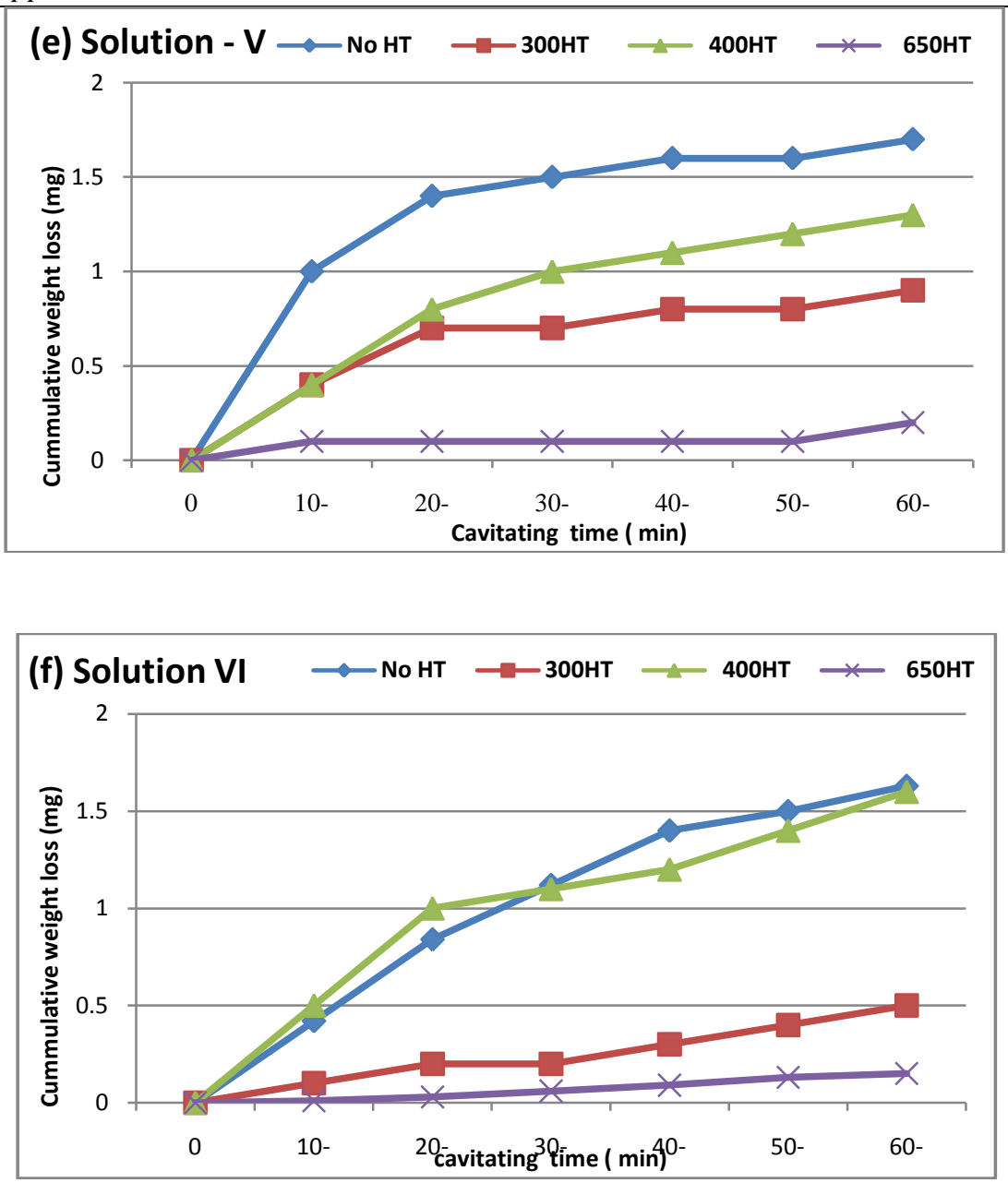

Fig. 6. Continue

\section{References}

[1] Zhang-xiong, D, Wei1, C., Qun, W.: Resistance of cavitation erosion of multimodal WC12Co coatings sprayed by HVOF. Trans. Nonferrous Met. Soc. China, 21, pp.2231-2236. (2011)

[2] Smith, N.M.: The fantastic potential of electroless nickel", Proceedings of the Electroless Nickel Conference, Cincinnati, pp.24-28.(1979).

[3] Sahoo, P., Das, S. K.: Tribology of electroless nickel coatings - A review. Materials and Design, 32(4), 1760-1775. (2011)

[4] Lo, P. H., Tsai, W. T., Lee, J. T., Hung, M. P.: Role of phosphorus in the electrochemical behavior of electroless Ni-P Alloys in 3.5 wt.\% NaCl solutions. Surf. Coat. Technol., pp. 67, pp.27-34. (1994)

Journal of Engineering Sciences, Assiut University, Faculty of Engineering, Vol. 41, No. 5, September, 2013, E-mail address: jes@aun.edu.eg 
Effect of Heat Treatment and Bath Composition of Electroless Nickel-Plating on Cavitation Erosion Resistance, pp. 1989 - 2011

[5] Apachitei, I., Duszczyk, J.: Autocatalytic nickel coatings on aluminum with improved abrasive wear resistance. Surf. Coat. Techno., 132(1), pp.89-98. (2000)

[6] Apachitei, I. Tichelaar, T. D. Duszczyk J., Katgerman, L.: The effect of heat treatment on the structure and abrasive wear resistance of autocatalytic NiP and NiP-SiC coatings. Surf. Coat. Technol., 149(2-3), pp.263-278. (2002)

[7] Keong, K. G., Sha W., Malinov, S.: Hardness evolution of electroless nickel-phosphorus deposits with thermal processing. Surf. Coat. Technol. 168, pp.263- 274. (2003)

[8] Ashassi-Sorkhabi, H., Rafizadeh S.H.: Effect of coating time and heat treatment on structures and corrosion characteristics of electroless Ni-P alloy deposits. Surf Coat Technol.176(3), pp.318-26. (2003)

[9] Bolger, P. T. and Szlag, D. C.: Current and emerging technologies for extending the lifetime of electroless nickel plating baths," Clean Products and Processes, 4, pp.209-219. (2001)

[10] Tarozaite R., Stalnionis, G.: Investigation of electroless nickel plating from Ni(II)-citrate solutions containing adipate and $\mathrm{Cu}(\mathrm{II})$ as Additives. CHEMIJA. 15(1), pp.1-6. (2004)

[11] Lin, C.J. He, J.L.: Cavitation erosion behavior of electroless nickel-plating on AISI 1045 steel. Wear, 259, pp.154-159. (2005)

[12] Lin, C.J., Chen, K.C., He, J.L.: The cavitation erosion behavior of electroless Ni-P-SiC composite coating. Wear, 261, pp.1390-1396. (2006)

[13] Preece, C.M. Hansson, I.L.H.: A Metallurgical approach to cavitation erosion, advances in the mechanics and physics of surfaces. R.M. Latanision and R.J. Courtei, Ed., Harwood Academic, 1, pp.199-253. (1981)

[14] Ahmed, S. M., Hokkirigawa, K., Oba, R. and Kikuchi, K.: SEM observation of vibratory cavitation fracture mode during the incubation period and the small roughness effect. JSME Int. J. Ser. II., 34(3), pp.298. (1991),

[15] Ahmed, S.M., Hokkirigawa, K., Oba, R.: Fatigue failure of SUS 304 caused by vibratory cavitation erosion. Wear, 177, pp.129-137. (1994).

[16] Ahmed, S. M., "Investigation of the temperature effects on induced impact pressure and cavitation erosion. Wear, 218, pp.119-127. (1997)

[17] Abouel-Kasem, A., Ahmed, S. M.: Cavitation erosion mechanism based on analysis of erosion particles. Trans. ASME, J. Tribol., 130, pp.031601. (2008)

[18] Abouel-Kasem, A., Emara, K. M., and Ahmed, S. M.: Characterizing cavitation erosion particles by analysis of SEM image. Tribol. Int., 42, pp.130-136. (2009)

[19] Abouel-Kasem, A., Baha, S., Ahmed, S. M.: Quantitative analysis of cavitation erosion particle morphology in dilute emulsions. Trans. ASME, J. Tribol., 130, pp.041603-1. (2008)

[20] Vaidya, S., Preece, C. M.: Cavitation erosion of age hardenable aluminum alloys. Metall. Trans. A, 9A, pp.299-307. (1978)

[21] Wade, H.R., Preece, C.M.: Cavitation erosion of iron and steel. Metal Trans, 9A, pp.1299310. (1978)

[22] Bedkowski, W., Gasiak G., Lachowicz, C., Lichtarowicz, A., Lagoda, T., Macha E.: Relations between cavitation erosion resistance of materials and their fatigue strength under random loading. Wear, 230, pp.201-209. (1999),

[23] Richman, R. H. McNaughton, W. P.: Correlation of cavitation erosion behavior with mechanical properties of metals. Wear, 140, pp.63-82. (1990)

Journal of Engineering Sciences, Assiut University, Faculty of Engineering, Vol. 41, No. 5, September, 2013,E-mail address: jes@aun.edu.eg 
[24] ASM Handbook, Volume 1, properties and selection: Irons, steels, and high performance alloys, ASM International, Materials Park, Ohio, (2005).

[25] Vyas, B. and Preece, C.M.: Stress produced in a solid by cavitation. J.Appl. Phys., 47, pp.5133-5138. (1976).

[26] ASTM-G-32-09.: Standard test method for cavitation erosion using vibratory apparatus. Annual book of ASTM standards. ASTM, Philadelphia, PA, (2009)

[27] Saleh, B., Abouel-Kasem, A., Ezz El-Deen, A., Ahmed, S.M.: Investigation of temperature effects on cavitation erosion behavior based on analysis of erosion particles. Trans. ASME, J. Tribol., 132, pp.031601. (2010)

[28] Rabizadeh, T., Allahkaram, S.R., Zarebidaki, A.: An investigation on effects of heat treatment on corrosion properties of Ni-P electroless nano-coatings. Materials and Design, 3, pp.3174-3179. (2010)

[29] Krishnamoorthy, P.R., Narayana, B.H., Ramakrishna, T.V., Shekhar Kumar, M.: Properties of electroless nickel-phosphorus deposits after crystallization. Metal Finish, 90(11), pp.13-17. (1992)

[30] Guo, Z. Keong, K.G. Sha, W.: Crystallisation and phase transformation behaviour of electroless nickel phosphorus platings during continuous heating. J. of Alloys and Compounds, 358, pp.112-119. (2003)

[31] Randin, J.P., Maire, P.A., Saurer, E., Hintermann, H.E.: DTA and X-ray studies of electroless nickel. J. Electrochem. Soc., 114(12), pp.442-445. (1967)

[32] Keong, K.G., Sha, W., Malinov, S.: Crystallisation kinetics and phase transformation behaviour of electroless nickel-phosphorus deposits with high phosphorus content. J. of Alloys and Compounds, 334, pp.192-199. (2002)

[33] Johnson, C. E., Ogburn, F.: Hardness of heat treated electroless nickel, Surface Technology, 4, pp.161-172. (1976)

[34] Keong, K.G., Sha, W., Malinov, S.: Hardness evolution of electroless nickel-phosphorus deposits with thermal processing. Surf. Coat. Technol., 168, pp.263-274. (2003)

[35] Balaraju, J.N., Sankara Narayanan, T.S.N, Seshadri, S.K.: Electroless Ni-P composite coatings. J. of Appl. Electrochem., 33, pp.807-816. (2003)

[36] Sahoo, P., Das, S. K.: Tribology of electroless nickel coatings -A review. Materials \& Design, 32, pp.1760-1775. (2011)

[37] Berríosa, J.A., Staiaa, M.H., Hernándeza, E.C., Hintermannb, H., Puchi, E.S.: Effect of the thickness of an electroless Ni-P deposit on the mechanical properties of an AISI 1045 plain carbon steel. Surface and Coatings Technology,108-109, pp.466-472. (1998)

[38] Hsu, C.H., Chiu, S.C., Shih, Y.H.: Effects of thickness of electroless Ni-P deposit on corrosion fatigue damage of 7075-T6 under salt spray atmosphere. Materials Transactions, The Japan Institute of Metals, 45,(11), pp.3201-3208. (2004)

Journal of Engineering Sciences, Assiut University, Faculty of Engineering, Vol. 41, No. 5, September, 2013, E-mail address: jes@aun.edu.eg 
Effect of Heat Treatment and Bath Composition of Electroless Nickel-Plating on Cavitation Erosion Resistance, pp. 1989 - 2011

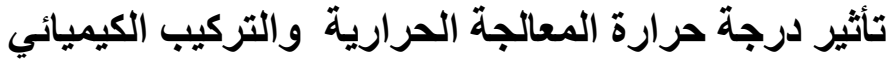

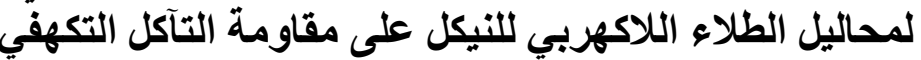

الملخص العربى

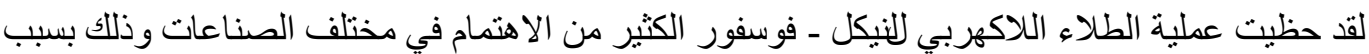

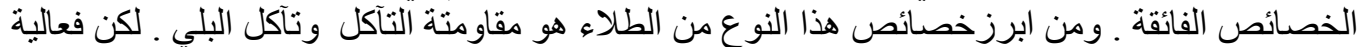

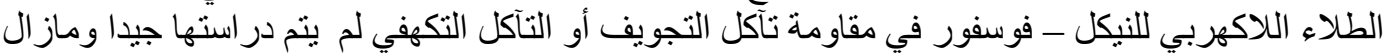
يشوبها شيء من الغموض ـ في هذا البحث ثم تطبيق الطلاء اللاكهربي للنيكل فوسفور باستخدام تر اكيب

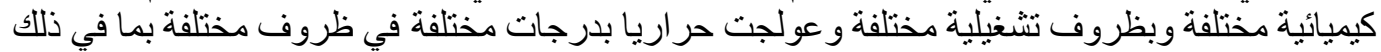

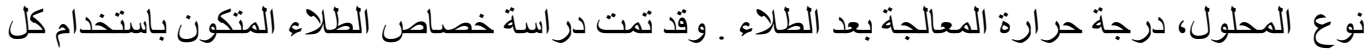

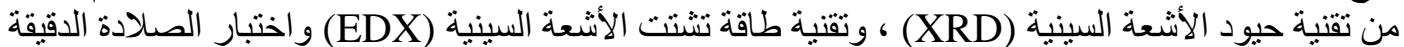

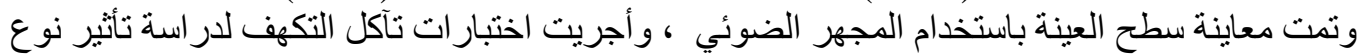

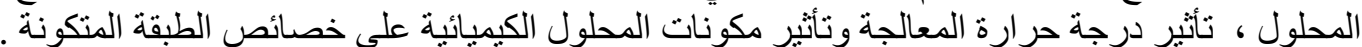

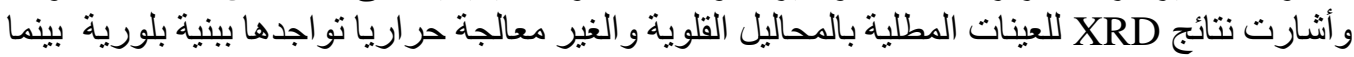

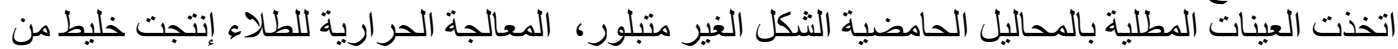

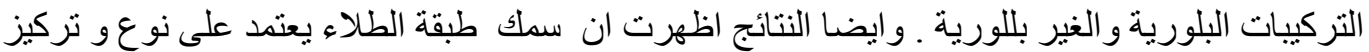

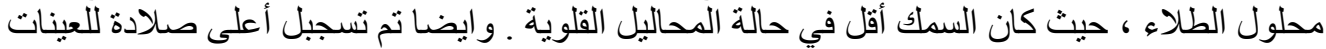

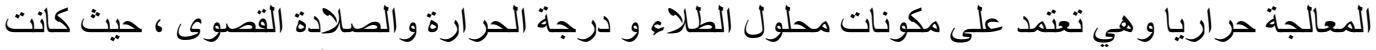

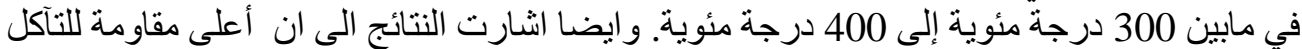
التكهفي للطلاء سجلت في حالة العينات المعالجة حر اريا عند درجة حرارة

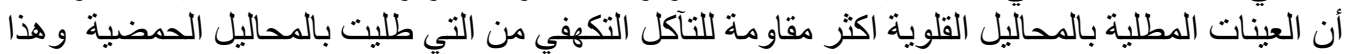

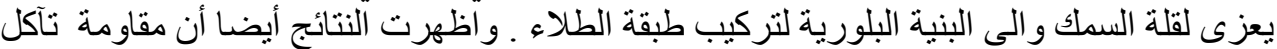

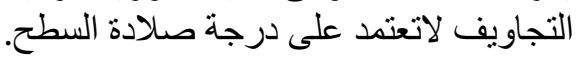

Journal of Engineering Sciences, Assiut University, Faculty of Engineering, Vol. 41, No. 5, September, 2013,E-mail address: jes@aun.edu.eg 